\title{
SMART CAMPUS POLITEKNIK LP3I BANDUNG
}

\author{
Hadiansyah Ma'sum, S.Pd., S.T., M.Kom. \\ Dosen Program Studi Manajemen Informatika \\ Politeknik LP3I Bandung \\ E-Mail : kanghadiansyah@gmail.com
}

\begin{abstract}
Abstrak : Peranan Teknologi Informasi \& Komunikasi (TIK) dalam dunia pendidikan juga sangat besar, khususnya dalam hal penunjang proses belajarmengajar dan efisiensi pekerjaan akademik maupun administratif. Perguruan tinggi sebagai salah satu institusi pendidikan sudah selayaknya mampu untuk memanfaatkan teknologi informasi dan komunikasi dalam menunjang berbagai aktivitasnya. Penetrasi dan implementasi teknologi informasi dan komunikasi pada perguruan tinggi akan memberikan dampak yang sangat positif serta diharapkan memberikan efisiensi dan produktivitas yang tinggi dalam bidang akademik dan administratif. Selain itu, dengan implementasi dan adaptasi teknologi informasi dan komunikasi diharapkan juga agar perguruan tinggi tersebut mampu terus bersaing dalam kancah persaingan dunia pendidikan di tingkat Nasional bahkan Internasional.
\end{abstract}

Politeknik LP3I Bandung sebagai salah satu perguruan tinggi berbasis vokasi di Indonesia sudah melakukan implementasi dan adaptasi teknologi informasi dan komunikasi. Keberhasilan Politeknik LP3I Bandung dalam menjalin berbagai kerja sama dengan pihak perusahaan dalam bidang teknologi informasi dan komunikasi juga telah memberikan dampak positif bagi perkembangan teknologi informasi dan komunikasi di Politeknik LP3I Bandung dan juga membuat 'pamor' Politeknik LP3I Bandung dikenal sebagai salah satu perguruan tinggi dengan riset teknologi informasi dan komunikasi yang terkemuka.

Sebagai bukti telah memanfaatkan teknologi informasi dan komunikasi pada tahun 2014 Politeknik LP3I Bandung mendapatkan penghargaan TeSCA sebagai OUTSTANDING TESCA ACHIEVER: AKADEMI \& POLITEKNIK. Program TeSCA yang diinisiasi oleh PT Telekomunikasi Indonesia Tbk bekerjasama dengan Dirjen Perguruan Tinggi (Dikti) Kementerian Pendidikan dan Kebudayaan, Dewan Teknologi dan Komunikasi Nasional (Detiknas), dan Asosiasi Perguruan Tinggi Ilmu Komputer (Aptikom).

Kata Kunci : Smart Campus, TeSCA, Teknologi Informasi dan komunikasi

\section{Pendahuluan}

Teknologi informasi dan komunikasi saat ini sudah merupakan bagian yang tidak dapat dipisahkan dari kehidupan manusia modern. Teknologi informasi dan komunikasi memberikan dampak yang sangat positif dalam berbagai hal, di antaranya: pendukung pengambilan keputusan; peningkatan efisiensi dan produktivitas; penunjang aktivitas pekerjaan dan belajar; dan bahkan dapat meningkatkan mutu hidup manusia. Peranan teknologi informasi dan komunikasi 
akan semakin meningkat seiring perkembangan jaman dan hingga akhirnya menjadi elemen dasar dalam kehidupan mahluk penghuni bumi ini.

Peranan teknologi informasi dan komunikasi dalam dunia pendidikan juga sangat besar, khususnya dalam hal penunjang proses belajar-mengajar dan efisiensi pekerjaan akademik maupun administratif. Perguruan tinggi sebagai salah satu institusi pendidikan sudah selayaknya mampu untuk memanfaatkan teknologi informasi dan komunikasi dalam menunjang berbagai aktivitasnya.

Penetrasi dan implementasi teknologi informasi dan komunikasi pada perguruan tinggi akan memberikan dampak yang sangat positif serta diharapkan memberikan efisiensi dan produktivitas yang tinggi dalam bidang akademik dan administratif. Selain itu, dengan implementasi dan adaptasi teknologi informasi dan komunikasi diharapkan juga agar perguruan tinggi tersebut mampu terus bersaing dalam kancah persaingan dunia pendidikan di tingkat Nasional bahkan Internasional.

Politeknik LP3I Bandung sebagai salah satu perguruan tinggi berbasis vokasi di Indonesia sudah melakukan implementasi dan adaptasi teknologi informasi dan komunikasi. Berawal dari Sistem Informasi Administrasi Akademik (SIAKAD), dan Sistem Informasi Administrasi Keuangan (SIAKEU), didukung dengan prasarana jaringan komputer yang cukup memadai telah terpasang. Hubungan ke jaringan internet, dan layanan berbasis web seperti website dan email juga telah tersedia. Dengan sumber daya manusia teknologi informasi dan komunikasi yang dimiliki lembaga-lembaga di atas, berbagai aplikasi teknologi informasi dan komunikasi juga dikembangkan, diimplementasikan, dan telah digunakan. Selain itu keberhasilan Politeknik LP3I Bandung dalam menjalin berbagai kerja sama dengan pihak perusahaan dalam bidang

teknologi informasi dan komunikasi juga telah memberikan dampak positif bagi perkembangan teknologi informasi dan komunikasi di Politeknik LP3I Bandung dan juga membuat 'pamor' Politeknik LP3I Bandung dikenal sebagai salah satu perguruan tinggi dengan riset teknologi informasi dan komunikasi yang terkemuka.

Penerapan teknologi informasi dan komunikasi di Politeknik LP3I Bandung bukan tanpa kendala dan permasalahan. Pengembangan teknologi informasi dan komunikasi masih belum terpadu dengan aktivitas pengembangan lain khususnya dalam bidang akademik dan belajar-mengajar. Masih banyak terjadi tumpang-tindih kepentingan dan pengembangan antar berbagai lembaga di Politeknik LP3I Bandung.

\section{Landasan Teori}

\subsection{Smart Campus}

Smart Campus sebagai salah satu program pemanfaatan ICT di berbagai Kampus perguruan Tinggi. Penerapan ICT secara tepat akan meningkatkan pelayanan pada mahasiswa dan masyarakat sekaligus meningkatkan citra 
kampus sebagai center of excellence. Smart Campus merupakan layanan total solusi informasi dan komunikasi terintegrasi untuk kebutuhan komunikasi multimedia. Pengembangan Smart Campus mencakup penyediaan infrastruktur, penyediaan layanan dasar kampus, aplikasi dan content, serta pengelolaan bisnis dan kustomer di lingkungan kampus. (Telkom Smart Campus, 2008:4,19).

Indikator keberhasilan smart campus adalah apabila kebutuhan pemakai dan pelanggan dapat dipenuhi dengan memuaskan dan konsisten. Untuk itu perlu didukung dengan pola bisnis yang sesuai, sehingga pelayanan dapat berkelanjutan dan tidak memberatkan pemakai. (Telkom Smart Campus, 2008)

\subsection{TeSCA}

TeSCA adalah sebuah program self assessment untuk mengukur pemanfaatan Teknologi Informasi \& Komunikasi (TIK) perguruan tinggi di Indonesia dengan menggunakan metode "ZEN Framework" yang akan mengukur beragam komponen mulai dari infrastuktur, aplikasi, sumberdaya manusia, hingga komponen kebijakan dan sebagainya.

TeSCA diinisiasi oleh PT Telekomunikasi Indonesia Tbk bekerjasama dengan Dirjen Perguruan Tinggi (Dikti) Kementerian Pendidikan dan Kebudayaan, Dewan Teknologi dan Komunikasi Nasional (Detiknas), dan Asosiasi Perguruan Tinggi Ilmu Komputer (Aptikom).

"ZEN Framewok" adalah suatu metodologi self assessment yang dikembangkan tiga profesor yang juga bertindak sebagai Dewan Juri TeSCA, yaitu : Prof. Zainal A. Hasibuan, Ph.D, Prof. Dr. Richardus Eko Indrajit, dan Prof. Ir. Nizam MSc., Ph.D.

Metode ini tersusun atas delapan parameter penilaian yaitu : (1) Suprastruktur Kampus, (2) Infrastruktur Teknologi, (3) Profil Pemangku Kepentingan, (4) Ragam Pemanfaatan Aplikasi, (5) Strategi Pendidikan Nasional, (6) Dampak dan Manfaat Penerapan Teknologi, (7) Komunitas Eksternal dan (8) Adopsi Trend.

Selanjutnya dari delapan parameter tersebut, dikembangkan ke dalam 39 sub parameter, yang kemudian diwujudkan menjadi 120 buah pertanyaan / kuesioner yang terkait pengukuran dan perkembangan pemanfaatan TIK di perguruan tinggi.

\subsection{Manfaat mengikuti TeSCA}

Setiap perguruan tinggi yang berpartisipasi akan mendapatkan laporan nilai indeks pemanfaatan TIK secara total, berdasarkan indikator/parameter dan sub parameter, sebagai bahan evaluasi untuk melakukan peningkatan (self assessment). 
Indikator pengukuran dan standar implementasi yang ditetapkan dalam konsep TeSCA, memungkinkan perguruan tinggi memiliki rujukan yang tepat dalam mengembangkan langkah untuk meningkatkan kapasitas dan kualitasnya secara mandiri melalui pemanfaatan TIK.

Penilaian / indeks dari Program TeSCA akan sangat membantu pemerintah (melalui Dirjen Perguruan Tinggi Kemendikbud) memiliki peta yang cukup komprehensif untuk melihat seberapa besar kesenjangan yang terjadi di setiap perguruan tinggi guna menentukan langkah yang bisa dilakukan dengan program kongkret sebagai langkah perbaikan untuk mengatasi kesenjangan tersebut.

\subsection{Tahapan Penilaian TeSCA}

1. Self Assessment

Tahapan pengisian kuesioner secara online oleh personal in charge yang ditunjuk resmi oleh pihak perguruan tinggi melalui surat rekomendasi.

2. Desk Audit

Kuesioner yang telah diisi lengkap, selanjutnya dilakukan penilaian dan perhitungan indeks oleh tim juri yang terdiri dari dewan juri dibantu oleh beberapa narasumber yang berkompeten di bidangnya. Pada tahap ini akan menghasilkan pemeringkatan sementara.

3. Site Visit

Melakukan kunjungan kepada 20 perguruan tinggi yang telah dipilih pada tahap desk audit dengan tujuan untuk melakukan verifikasi langsung ke lokasi. Kunjungan akan dilakukan oleh tim yang merupakan representasi dari tim juri.

4. Penjurian Akhir

Tahapan final penentuan indeks dan peringkat oleh tim juri berdasarkan hasil desk audit dan site visit.

Kategori Penilaian TeSCA :

1. Kategori Nasional

2. Kategori Wilayah MP3EI (Jawa, Sumatera, Bali \& Nusa Tenggara, Sulawesi, Kalimantan, papua dan Maluku)

3. Kategori Perguruan Tinggi (Universitas, Institut, Politeknik, Sekolah Tinggi dan Akademi)

\section{Smart Campus Politeknik LP3I Bandung}

\subsection{Manfaat ICT}

Program pelayanan teknologi informasi dan komunikasi dirancang, disusun dan dilaksanakan agar dapat memberikan sebesar-besarnya manfaat bagi semua pihak, khususnya civitas academica Politeknik LP3I Bandung.

1.. Pimpinan:

a. Teknologi informasi dan komunikasi dapat menjadi alat bantu pengambil keputusan yang sangat akurat, cepat, cermat dan terpercaya. 
b. Teknologi informasi dan komunikasi memberikan kemudahan dalam berinteraksi dan berkomunikasi dengan segenap civitas akademik

\section{Dosen:}

a. Teknologi informasi dan komunikasi digunakan sebagai alat bantu penunjang proses belajar mengajar di kelas maupun di luar kelas.

b. Dosen dapat berinteraksi langsung dengan mahasiswa melalui email, teleconference, maupun voice chat.

c. Layanan Internet dapat dimanfaatkan dosen guna menunjang penelitian, melaksanakan proses belajar mengajar jarak jauh, pencarian informasi studi lanjut maupun komunikasi dan interaksi dengan dunia luar.

3. Mahasiswa:

a. Teknologi informasi dan komunikasi dapat menjadi salah satu sarana penunjang proses belajar-mengajar yang efektif dan efisien.

b. Mahasiswa dapat berinteraksi dengan dosen maupun dengan ilmuwan lain melalui e-mail, website, teleconference maupun voice chat.

c. Mahasiswa dapat memanfaatkan teknologi informasi dan komunikasi untuk mengakses sumber informasi dan pangkalan pengetahuan guna menunjang proses belajarnya di Politeknik LP3I Bandung.

4. Pegawai:

a. Teknologi informasi dan komunikasi dapat menjadi sarana bagi pekerjaanpekerjaan administratif yang memberikan efisiensi dan produktivitas kerja yang tinggi.

5. Alumni

a. Teknologi informasi dan komunikasi menjadi suatu sarana interaksi dan komunikasi alumni dengan alma maternya

b. Dapat meningkatkan kebanggaan terhadap alma mater sehingga secara langsung maupun tidak langsung dapat meningkatkan nilai tambah dan nilai jual alumni Politeknik LP3I Bandung.

\subsection{Analisis SWOT}

Dalam melakukan analisis kelayakan, digunakan analisis SWOT. Ada empat aspek yang akan ditinjau, yaitu: kekuatan (strength), kelemahan (weakness), peluang (opportunities) dan ancaman (threats).

\section{Kekuatan}

Faktor internal yang menjadi elemen kekuatan yang dimiliki oleh Politeknik LP3I Bandung saat ini dalam hal pengembangan teknologi informasi dan komunikasi, dapat dijabarkan dalam butir-butir berikut:

a. Manajemen dan Kebijakan:

Dukungan dari pihak pimpinan, yaitu dengan adanya kebijakan dan kemauan untuk mengembangkan teknologi informasi dan komunikasi.

Komitmen pimpinan Politeknik LP3I Bandung untuk mengembangkan, memanfaatkan dan mengelola teknologi informasi dan komunikasi sebagai sarana pendukung kegiatan-kegiatan kampus

b. Prasarana dan Sumber Daya: 
1) Tersedianya prasarana teknologi informasi dan komunikasi yang sudah terpasang di kampus Politeknik LP3I Bandung. Jaringan intranet dengan backbone utama serat optik yang hampir mencapai seluruh gedung di kampus dan komputer yang terhubung yang terus bertambah.

2) Beragam layanan teknologi informasi dan komunikasi yang telah diimplementasikan di kampus berbasis LAN maupun digunakan masyarakat yang berbasis website.

Teknologi informasi dan komunikasi berbasis LAN terdiri dari SIAKAD, SIADOSEN, SIAMHS, SIAKRS, SIAKEU, SIAPA, SIAPMB, dan SIACNP dengan menggunakan Windows 2003 Server dan database MS-SQL Server, network monitoring, troubleshooting, pemeliharaan dan lain-lain.

Teknologi informasi dan komunikasi berbasis internet terdiri dari domain master website dengan alamat www.plb.ac.id, dengan sub domain sebagai berikut : Siakad ONLINE, Perpustkaan Digital, Wisuda, Tabloid News, CnP, Forum, In House Training, Rubrik Konsultasi dan Web Mail.

3) Tersedianya sumber daya manusia bidang IT yang tersebar di unit-unit kerja lingkungan Politeknik LP3I Bandung untuk memelihara dan menangani permasalah yang adan serta untuk pengembangan sumber daya manusia yang menguasai teknologi informasi di masa mendatang.

4) Adanya dukungan dana dari mahasiswa dan proyek-proyek hibah, seperti program-program PHP dan program cakupan perguruan tinggi.

c. Kondisi Kampus:

1) Nama Politeknik LP3I Bandung sudah cukup dikenal sebagai salah satu perguruan tinggi yang konsisten dan terdepan dalam pengembangan teknologi informasi dan komunikasi.

2) Letak geografis kampus Politeknik LP3I Bandung yang banyak menunjang untuk keperluan teknologi informasi dan komunikasi.

3) Komunitas kampus yang besar jumlahnya (mahasiswa, alumni, dosen, karyawan), perusahaan dan juga masyarakat sekitar kampus, baik masyarakat akademis (mahasiswa lain) maupun masyarakat biasa.

4) Tingkat keinginan mahasiswa, dosen dan karyawan akan layanan teknologi informasi di Politeknik LP3I Bandung cukup tinggi.

5) Politeknik LP3I Bandung sudah dapat menjual beberapa produk teknologi informasi dan komunikasinya karena sudah mempunyai lisensi.

d. Kerja Sama, Riset Unggulan dan Prestasi:

1) Adanya kerja sama Politeknik LP3I Bandung dengan pihak luar (BINUS, POLBAN, POLTEKNIK TELKOM, APTIKOM, MUGI dan lain-lain) dalam penerapan dan pengembangan teknologi informasi.

2) Adanya riset dan seminar unggulan dalam bidang teknologi informasi dan komunikasi: E-Management, E-Learning, Smart Campus dan lain-lain.

\section{Kelemahan}

Selain memiliki kekuatan, terdapat juga sejumlah kelemahan. Berikut butir-butir kelemahan yang dikelompokkan dalam beberapa kriteria.

a. Manajemen, Kebijakan dan Struktur Organisasi: 
1) Belum ada arah pengembangan teknologi informasi dan komunikasi Politeknik LP3I Bandung yang dapat dijadikan acuan bagi pengembangan dan penerapan teknologi informasi di masa mendatang dengan pola berkesinambungan dan terarah.

2) Keterpaduan antar bidang baik dalam kaitan dengan teknologi informasi maupun bidang-bidang lainnya belum baik, karena belum ada struktur dan aturan rinci yang komprehensif mengenai hubungan antar bidang, terutama yang berkaitan dengan teknologi informasi.

3) Belum ada badan usaha profit resmi kampus yang memberikan dukungan langsung kepada pengembangan teknologi informasi dan komunikasi di Politeknik LP3I Bandung.

4) Pendanaan untuk pelayanan dan pengembangan teknologi informasi masih mengandalkan pada dana institusi dan mahasiswa, belum pada ke arah pendanaan sinambung dan lestari (sustainable).

b. Sumber Daya Manusia dan Implementasi Aplikasi/Layanan:

1) Belum ada penghargaan khusus yang memadai bagi karyawan dan dosen yang mempunyai keahlian dan bekerja di bidang teknologi informasi.

2) Politeknik LP3I Bandung belum dapat menjual beberapa produk teknologi informasi dan komunikasinya secara luas karena belum mempunyai tim marketing khusus.

c. Prasarana:

1) Pelatihan sumber daya manusia masih sangat kurang karena seluruh laboratorium terpakai oleh jadwal perkuliahan.

\section{Peluang}

Berikut rincian peluang yang ada saat ini maupun akan datang yang seharusnya menjadi bahan pertimbangan:

a. Peluang Usaha:

1) Pengembangan teknologi informasi dan komunikasi dapat berfungsi sebagai suatu profit center kampus.

2) Pasar teknologi informasi dan komunikasi yang masih luas di bidang pendidikan dan pemerintahan.

3) Hasil pengembangan produk internal yang siap dipasarkan ke luar kampus.

4) Memfungsikan fasilitas yang sudah terpasang di Politeknik LP3I Bandung sebagai Internet Service Provider lokal Kota Bandung.

5) Kebutuhan akan teknologi informasi di berbagai bidang terutama adanya otonomi daerah dan tumbuhnya apresiasi masyarakat terhadap penggunaan teknologi informasi dan komunikasi, baik karena mengikuti trend teknologi maupun kebutuhan akan kecepatan akses, keakuratan dan keterbukaan informasi.

6) Belum banyak lembaga pendidikan yang menyertakan sertifikasi teknologi informasi berstandar nasional dan internasional bagi lulusannya.

b. Riset dan Penelitian 
1) Banyaknya tawaran kerja sama di bidang teknologi informasi dan komunikasi dari berbagai pihak, terutama dalam bentuk kerja sama dalam pelatihan dan lisensi produk teknologi informasi, karena Politeknik LP3I Bandung telah semakin dikenal sebagai salah satu politeknik terkemuka dalam pengembangan dan penerapan teknologi informasi dan komunikasi

2) Perkembangan riset di bidang teknologi informasi dan komunikasi di Indonesia masih cukup terbuka. Politeknik LP3I Bandung memiliki cukup riset unggulan yang dapat dijadikan andalan.

3) Adanya dana-dana kompetitif baik dari Direktorat Pendidikan Tinggi, Departemen Pendidikan Nasional maupun dari sumber lainnya yang dapat juga digunakan untuk pengadaan prasarana dan peningkatan kemampuan sumber daya manusia di bidang teknologi informasi dan komunikasi.

4) Adanya open source yang dapat digunakan dan dikembangkan dengan murah, sehingga akan memacu kreativitas bagi pengembang dan mahasiswa.

5) Sebagai sarana untuk penelitian dosen dan mahasiswa

6) Teknologi informasi dan komunikasi secara langsung maupun tidak langsung dapat memberikan imbas pada peningkatan daya saing mutu layanan dan mutu pendidikan.

7) Kerja sama dan bantuan riset nasional/internasional dalam bidang teknologi informasi dan komunikasi dengan memanfaatkan fasilitas yang telah terpasang di Politeknik LP3I Bandung.

\section{Ancaman}

Ancaman terhadap kesempatan pengembangan penguasaan teknologi informasi dan komunikasi ini terutama adalah karena teknologi informasi dan komunikasi ini merupakan teknologi yang cepat perkembangannya dan manfaat serta peluangnya dapat dirasakan oleh banyak pihak. Politeknik LP3I Bandung harustanggap terhadap ancaman ini jika tidak ingin peluang di atas diambil alih oleh pihak lain. Ancaman-ancaman itu antara lain adalah sebagai berikut:

a. Banyak perguruan tinggi lain di kota Bandung yang juga akan mengembangkan teknologi yang sama.

b. Perkembangan teknologi informasi dan komunikasi yang semakin cepat sehingga memicu kekunoan suatu teknologi yang diterapkan yang semakin pendek.

c. Jumlah dan mutu sumber daya manusia perguruan tinggi swasta di Bandung dan sekitarnya di bidang teknologi informasi dan komunikasi semakin meningkat.

d. Persaingan yang semakin ketat di bidang pengembangan dan pemanfaatan teknologi informasi dan komunikasi.

\subsection{Rancangan Program Pelayanan ICT}

Berikut adalah prinsip dasar pelayanan teknologi informasi dan komunikasi Politeknik LP3I Bandung yang harus menjadi orientasi saat ini dan 
masa datang:

1. Layanan akses untuk semua komponen kampus secara merata dan memadai.

2. Fokus pengembangan riset dan bidang ilmu masing-masing berbasis teknologi informasi dan komunikasi.

3. Menunjang layanan sistem informasi untuk berbagai aspek kegiatan kampus.

4. Berbagi sumber daya teknologi informasi dan komunikasi (resourcesharing).

5. Sumber biaya operasional dan pengembangan dari pengguna untuk pengguna.

6. Biaya akses layanan relatif murah dan terjangkau.

7. Efisiensi dan efektivitas kerja seluruh bidang serta peningkatan produktivitas kerja.

8. Politeknik LP3I Bandung sebagai pusat riset dan pengembangan teknologi informasi dan komunikasi skala nasional dan internasional.

\subsection{Rancangan Layanan}

Rancangan jenis layanan umum teknologi informasi dan komunikasi Politeknik LP3I Bandung antara lain adalah sebagai berikut:

1. Layanan Sistem Informasi Administrasi berbasis LAN.

2. Layanan Sistem Informasi Administrasi berbasis WAN.

3. Layanan Prasarana Jaringan dan Komputer.

4. Layanan Komunikasi dan Internet.

5. Layanan Teknologi Instruksional Pembelajaran.

6. Layanan Bisnis dan Pengguna.

Layanan Sistem Informasi Administrasi berbasis LAN

1. Sistem Informasi Administrasi Akademik (SIAKAD)

2. Sistem Informasi Administrasi Mahasiswa (SIAMHS)

3. Sistem Informasi Administrasi Dosen (SIADOSEN)

4. Sistem Informasi Administrasi Pembimbing Akademik (SIAPA)

5. Sistem Informasi Administrasi KRS (SIAKRS)

6. Sistem Informasi Administrasi Keuangan (SIAKEU)

7. Sistem Informasi Administrasi Penerimaan Mahasiswa Baru (SIAPMB)

8. Sistem Informasi Administrasi Kepegawaian (SIAHRD)

9. Sistem Informasi Administrasi Penempatan Magang dan Kerja (SIACNP)

10. Sistem Informasi Administrasi Perpustakaan (SIAPERPUS)

11. Sistem Informasi Administrasi Sarana Prasarana (SIAFASILITAS)

12. Sistem Informasi Administrasi Penelitian dan Pengabdian Masyarakat (SIAP2M)

Layanan Sistem Informasi Administrasi berbasis WAN

1. Sistem Informasi Kampus (http:// plb.ac.id) 
2. Sistem Informasi Akademik Online

3. Sistem Informasi Wisuda

4. Sistem Informasi Dosen

5. Sistem Informasi CNP

6. Sistem Informasi In House Training

7. Sistem Informasi Tabloid News

8. Sistem Informasi Perpustakaan Digital

9. Sistem Informasi E-Learning

10. Sistem Informasi KRS Online

11. Web Mail Karyawan

12. Web Mail Mahasiswa

13. Sistem Informasi Alumni

14. Sistem Informasi Kemahasiswaan

Untuk sistem informasi kemahasiswaan terdiri dari beberapa informasi BEM dan UKM, yaitu :

1. BEM Politeknik LP3I Bandung

2. UKM ICON Prodi Manajemen Informatika

3. UKM BIC Prodi Administrasi Bisnis

4. UKM LAC Prodi Akuntansi

5. UKM HIMASI Prodi Hubungan Masyarakat

6. UKM SICES

7. UKM Rohis

8. UKM RIMBARA

9. UKM LFC

Layanan Prasarana Jaringan dan Komputer

1. Campus Local Area Network

2. Wide Area Network

3. Network Operation Center

4. Data Center

5. Network Storage Center

6. Internet Connection

7. Students Computer Services

8. Computer Support Center

9. Data Security System

10. Computer and Network Technical Support

Layanan Komunikasi dan Internet
1. Internet Access User
2. Web Desain and Web Development
3. Web Hosting Service
4. Email Service
5. Official Web Site
6. Voice Over IP
7. SMS Gateway 
8. Messenger System

9. Video Conference System

10. Portal Service

11. Electronic Dropbox

Layanan Bisnis dan Pengguna

1. Custom Business Application Development.

2. Helpdesk/Call Center/Customer Care

3. User Billing System.

4. Legal Software Service.

5. SmartCard Service.

6. Internet Service Provider (ISP).

7. Application Service Provider (ASP).

8. Project Management Services

\section{Rancangan Jaringan Interet}

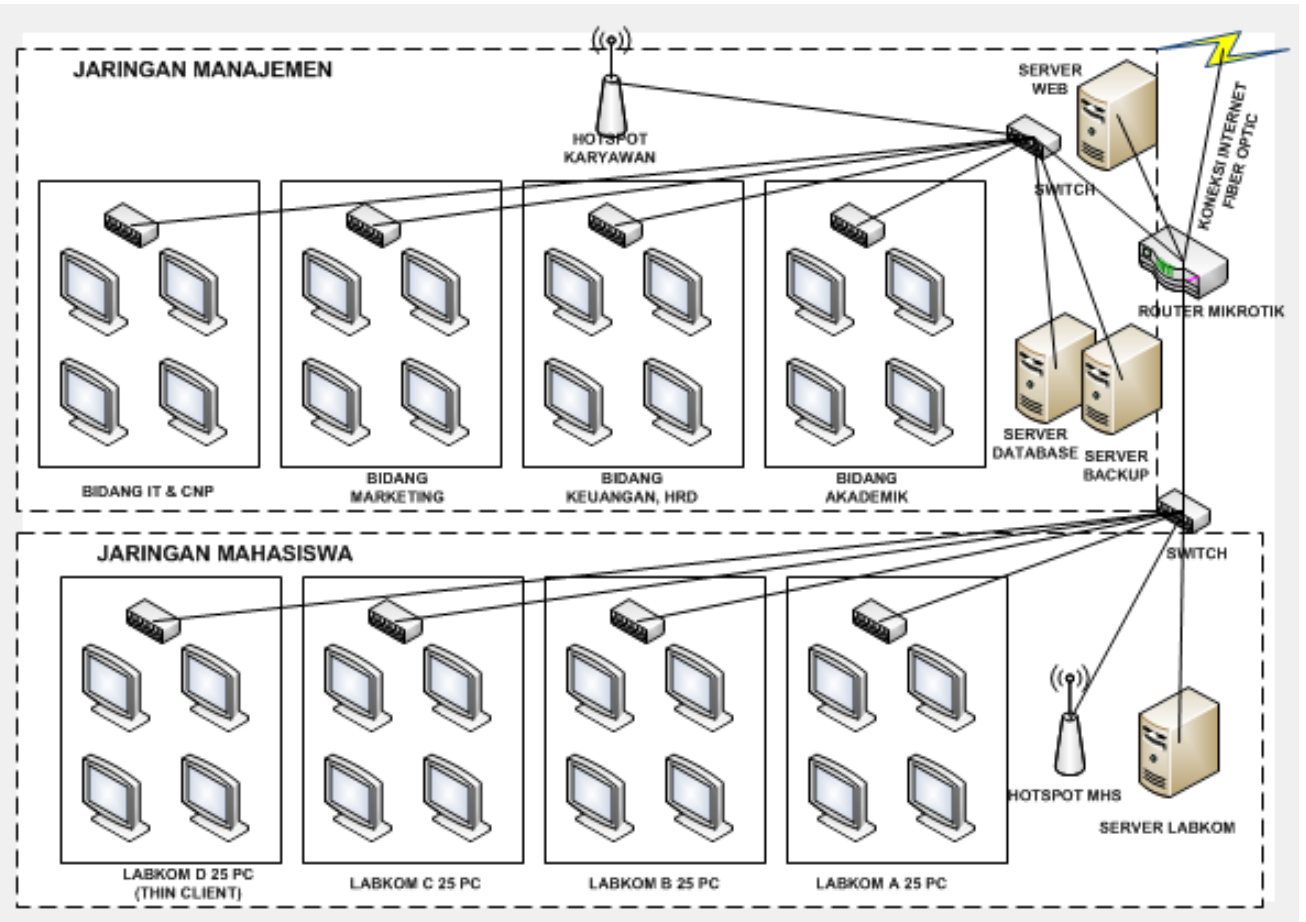

Gambar 4.1 Rancangan Jaringan 


\section{Rancangan jaringan komunikasi data}

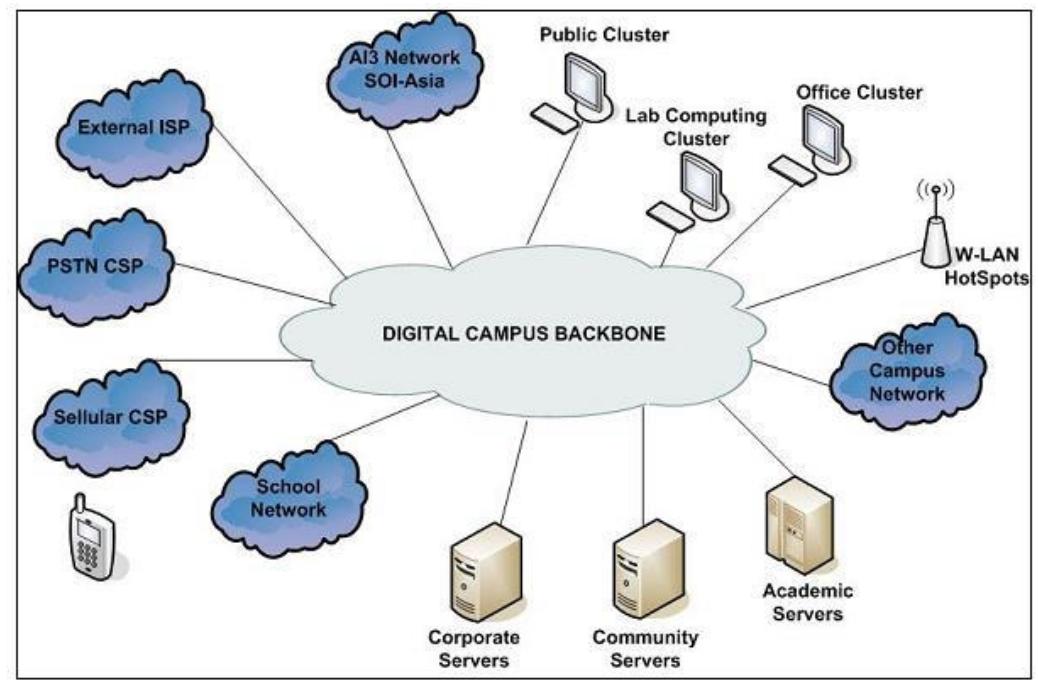

Gambar 4.2 Rancangan jaringan komunikasi data

\subsection{Rancangan Pengguna Dan Hak Akses}

Secara umum pengguna layanan teknologi informasi dan komunikasi adalah:

1. Pengguna Internal:
a. Pimpinan
b. Dosen
c. Karyawan/Staff
d. Mahasiswa
e. Program Studi
f. Unit Kegiatan Mahasiswa
g. Kepanitiaan

\section{Pengguna Eksternal:}
a. Tamu Resmi Kampus
b. Rekanan Kampus

Mengingat banyaknya pengguna layanan teknologi informasi dan komunikasi Politeknik LP3I Bandung tersebut, maka perlu dibuat suatu aturan mengenai hak akses dari para user tersebut. Kategori dari pengguna layanan teknologi informasi dan komunikasi dikelompokkan menjadi:
a. Pengembang (Developer)
b. Administrator/Super User
c. Pengguna Khusus (Power User)
d. Pengguna Biasa (Native User)
e. Tamu (Guest) 
Selain itu setiap pengguna juga memiliki hak akses yang berbeda yang membatasi kemampuan user tersebut dalam mengakses layanan teknologi informasi dan komunikasi yang diberikan. Jenis akses layanan tersebut adalah:

a. Akses Bebas: yaitu pengguna mendapat hak akses secara tetap untuk layanan dasar/umum.

b. Akses Temporer: pengguna mendapat hak akses yang bersifat sementara.

c. Akses Premium: pengguna mendapat hak akses untuk layanan yang bersifat tambahan/personal.

\section{Hasil Penilaian TeSCA 2014}

Hasil dari penilaian tim juri TeSCA 2014 menyetakan bahwa Politeknik LP3I Bandung mendapatkan penghargaan TeSCA sebagai OUTSTANDING TESCA ACHIEVER: AKADEMI \& POLITEKNIK. Dengan rincian nilai sebagai berikut :

\section{Chart Report TeSCA}

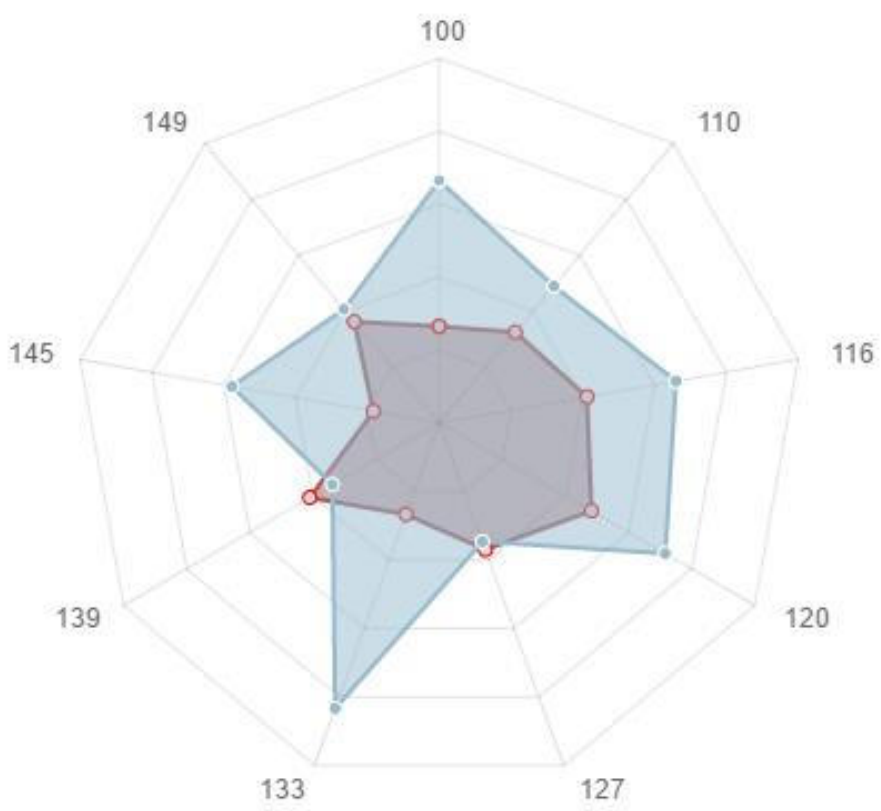

Gambar 4.3 Chart Report TeSCA

Penjelasan Tabel 4.1 Chart Report TeSCA

\begin{tabular}{|c|l|c|c|}
\hline No. & Indikator & Nilai & Rata-rata Nilai Nasional \\
\hline 100 & Suprastruktur & 4.323 & 2.626 \\
\hline 110 & Infrastruktur & 3.448 & 3.06 \\
\hline 116 & Profil Pemangku Kepentingan & 4.3 & 3.415 \\
\hline 120 & Ragam Pemanfaatan \& Aplikasi & 4.582 & 2.851 \\
\hline 127 & strategi Pendidikan Nasional & 2.733 & 2.337 \\
\hline
\end{tabular}




\begin{tabular}{|c|l|c|c|}
\hline No. & Indikator & Nilai & Rata-rata Nilai Nasional \\
\hline 133 & $\begin{array}{l}\text { Dampak \& Manfaat Penerapan } \\
\text { Teknologi }\end{array}$ & 5.169 & 3.05 \\
\hline 139 & Komunitas Eksternal & 2.691 & 1.917 \\
\hline 145 & Adopsi Trend & 3.887 & 2.813 \\
\hline 149 & index_value & 3.032 & 2.324 \\
\hline
\end{tabular}

Tabel 4.2 Daftar Nilai

\begin{tabular}{|c|c|c|c|}
\hline No. & Indikator & Nilai & $\begin{array}{l}\text { Rata-rata Nilai } \\
\text { Nasional }\end{array}$ \\
\hline 1 & Suprastruktur & 4.323 & 2.626 \\
\hline 2 & Komitmen Pimpinan & 3.844 & 2.351 \\
\hline 3 & Alokasi Sumber Daya & 3.667 & 2.547 \\
\hline 4 & Unit Pengelola Teknologi & 4 & 2.822 \\
\hline 5 & Kebijakan \& Sistem Insentif & 5.042 & 2.671 \\
\hline 6 & Renstra \& Peta Jalan & 5 & 2.673 \\
\hline 7 & Perencanaan \& Pengorganisasian & 4.68 & 2.765 \\
\hline 8 & Pengadaan \& Penerapan & 5.828 & 3.297 \\
\hline 9 & Pengelolaan \& Pengembangan & 3.441 & 2.369 \\
\hline 10 & Pemantauan \& Penilaian & 4.297 & 2.31 \\
\hline 11 & Infrastruktur & 3.448 & 3.06 \\
\hline 12 & Koneksi Jaringan & 3.957 & 3.309 \\
\hline 13 & Kanal Akses \& Perangkat Keras & 3.4 & 3.398 \\
\hline 14 & Piranti Lunak Sistem & 2 & 2.303 \\
\hline 15 & Gudang Data & 3.5 & 2.414 \\
\hline 16 & Pusat Kendali & 3 & 2.419 \\
\hline 17 & Profil Pemangku Kepentingan & 4.3 & 3.415 \\
\hline 18 & Dosen \& Peneliti & 4.102 & 3.194 \\
\hline 19 & $\begin{array}{l}\text { Mahasiswa, Unsur Pemilik/Pimpinan \& Pihak } \\
\text { Pengambil Keputusan dalam Institusi Perguruan } \\
\text { Tinggi }\end{array}$ & 4.531 & 4.141 \\
\hline 20 & Manajemen, Staf \& Karyawan Perguruan Tinggi & 5.063 & 3.795 \\
\hline 21 & Ragam Pemanfaatan \& Aplikasi & 4.582 & 2.851 \\
\hline 22 & Referensi Sumber Informasi \& Pengetahuan & 4.84 & 3.307 \\
\hline 23 & Alat Bantu \& Media Belajar-Mengajar & 4.855 & 2.945 \\
\hline 24 & Model Pembelajaran Virtual \& Mandiri & 3.633 & 2.393 \\
\hline 25 & $\begin{array}{l}\text { Otomatisasi Administrasi \& Operasional } \\
\text { Kampus }\end{array}$ & 5 & 3.19 \\
\hline 26 & Piranti Komunikasi, Kolaborasi \& Koordinasi & 5 & 2.486 \\
\hline
\end{tabular}




\begin{tabular}{|c|l|c|c|}
\hline No. & Indikator & Nilai & $\begin{array}{c}\text { Rata-rata Nilai } \\
\text { Nasional }\end{array}$ \\
\hline 27 & Sistem Pelaporan \& Pengambilan Keputusan & 5 & 2.173 \\
\hline 28 & strategi Pendidikan Nasional & 2.733 & 2.337 \\
\hline 29 & Implementasi e-learning & 3 & 2.602 \\
\hline 30 & Berbagi Sumber Daya & 3.383 & 2.374 \\
\hline 31 & Pendidikan Terbuka & 2.75 & 2.372 \\
\hline 32 & Pangkalan Data Terpadu & 3 & 2.495 \\
\hline 33 & Jejaring Internasional & 1 & 1.901 \\
\hline 34 & Dampak \& Manfaat Penerapan Teknologi & 5.169 & 3.05 \\
\hline 35 & Peningkatan Kualitas & 4.935 & 3.012 \\
\hline 36 & Efektivitas \& Efisiensi & 5.828 & 2.897 \\
\hline 37 & Transparansi Manajemen & 5.828 & 2.894 \\
\hline 38 & Utilitas Sumber Daya & 5 & 2.972 \\
\hline 39 & Transformasi Organisasi & 5 & 3.858 \\
\hline 40 & Komunitas Eksternal & 2.691 & 1.917 \\
\hline 41 & Pemerintah & 2 & 1.473 \\
\hline 42 & Industri & 3 & 1.982 \\
\hline 43 & Komunitas & 2.333 & 2.109 \\
\hline 44 & Akademisi & 3 & 1.847 \\
\hline 45 & Pemilik & 3.531 & 1.724 \\
\hline 46 & Adopsi Trend & 3.887 & 2.813 \\
\hline 47 & Penelitian \& Pengembangan & 3.459 & 2.404 \\
\hline 48 & Ramah Lingkungan & 4.238 & 2.571 \\
\hline 49 & Inovasi & 3.942 & 3.278 \\
\hline 50 & index_value & 3.032 & 2.324 \\
\hline & & $\mathbf{1 9 7 . 0 7 3}$ & \\
\hline
\end{tabular}

\section{Kesimpulan}

Berdasarkan hasil penelitian dan pembahasan tentang Smart Campus Politeknik LP3I Bandung, maka dapat ditarik kesimpulan yaitu:

1. TeSCA diinisiasi oleh PT Telekomunikasi Indonesia Tbk bekerjasama dengan Dirjen Perguruan Tinggi (Dikti) Kementerian Pendidikan dan Kebudayaan, Dewan Teknologi dan Komunikasi Nasional (Detiknas), dan Asosiasi Perguruan Tinggi Ilmu Komputer (Aptikom).

2. Politeknik LP3I Bandung mendapatkan penghargaan TeSCA sebagai OUTSTANDING TESCA ACHIEVER: AKADEMI \& POLITEKNIK pada tahun 2014 merupakan bukti dalam penerapan teknologi, informasi dan komunikasi di perguruan tinggi.

3. Penerapan ICT secara tepat akan meningkatkan pelayanan pada mahasiswa dan masyarakat sekaligus meningkatkan citra kampus. 


\section{Daftar Pustaka :}

[1] Abdul Kadir \& Terra Ch. Triwahyuni, "Pengenalan Teknologi Informasi”. Andi Offset. Yogyakarta, 2003

[2] Edy Susena, Ema Utami, Andi Sunyoto, "Perencanaan Strategis Sistem Informasi Smart Campus Untuk Meningkatkan Pelayanan Di Politeknik Indonusa Surakarta”, Jurnal Sainstech Politeknik Indonusa Surakarta ISSN : 2355-5009 Vol. 1 Nomor 3 Tahun 2015

[3] Munir, "Kontribusi Teknologi Informasi Dan Komunikasi (Tik) Dalam Pendidikan Di Era Globalisasi Pendidikan Indonesia”, Jurnal Pendidikan Teknologi Informasi Dan Komunikasi (PTIK), ISSN : 1979-9462, Vol. 2 no. 2 / Desember 2009

[4] Rankl, Wolfgang and Effing, Wolfgang. "Smart Card Handbook Third Edition.” s.1. : John Wiley \& Sons,Ltd, 2003.

[5] Direktorat EWS- Subdit Enterprise, "Telkom Smart Campus", 2008

[6] Tim Divisi IT, “Blue Print Politeknik LP3I Bandung”, 2010-2015

[7] http://www.tescaindonesia.org, Test Smart Campus Award, Telkom Indonesia, diakses pada 1 Desember 2015. 